Vol. I No. 3 - December 2020

\title{
The Implementation of Urban Drainage Maintenance to Reduce Inundation Risk
}

\author{
Case Study in Tegal, Indonesia \\ Wulan Nurindah Sari ${ }^{1}$, Ichiki Atsushi ${ }^{2}$, Shimizu Toshiyuki ${ }^{3}$, Dewanti $^{4}$ \\ Directorate General of Housing, Ministry of Public Works and Housing (PUPR), Jakarta, Indonesia ${ }^{1}$ \\ Graduate School of Science and Engineering (GSSE), Ritsumeikan University, Shiga, Japan ${ }^{2,3}$ \\ Civil and Environment Department, Universitas Gadjah Mada, Yogyakarta, Indonesia ${ }^{4}$ \\ wulan.nurindah@gmail.com; a-ichiki@se.ritsumei.ac.jp; shimiz-t@fc.ritsumei.ac.jp; \\ dewanti@ugm.ac.id
}

\begin{abstract}
Coastal cities with low elevation and mild slopes tend to be more vulnerable to the threat of floods and inundations. Expansion of impermeable areas caused by land conversion greatly diminishes a city's ability to cope with the threat. Urban drainage systems play a crucial role in controlling excess surface water and reducing the threat of flood and inundation. To maintain an urban drainage system within an optimum condition and to reduce inundation risk, various types of drainage maintenance activities have been implemented in Tegal. This research was conducted in five inundation prone areas in Tegal to analyze the impact of those maintenance activities to urban drainage conditions and in reducing inundation. GIS and statistical analysis revealed that from the numerous urban drainage maintenance activities that have been performed, drainage sediment cleanup has the most obvious impact on drainage conditions and in reducing inundation.
\end{abstract}

Keywords: Urban Drainage, Drainage Maintenance, Inundation Risk

ARTICLE INFO

Received: Jul 29, 2020

Received in revised form: Oct 29, 2020

Accepted: Nov 1, 2020
JISDeP - The Journal of Indonesia Sustainable Development Planning Published by Center for Planners'

Development, Education, and Training (Pusbindiklatren),

Ministry of National Development

Planning/ National Development

Planning Agency (Bappenas), Republic of Indonesia
Address: Jalan Proklamasi 70,

Central Jakarta, Indonesia 10320

Phone: +62 $2131928280 / 3192828$

Fax: +62 2131928281

E-mail: pusbindiklatren@bappenas.go.id

Supported by Indonesian Development Planners Association (PPPI) 


\section{Introduction}

Indonesia is the largest archipelagic state in the world with the second-longest coastline, wherein $60 \%$ of the population lives within a $50 \mathrm{~km}$ radius of the coastline (Kementerian Kelautan dan Perikanan, 2019; Suryadiputra, 2012). Annual flooding is very common in many cities in Indonesia, especially in coastal areas, which have a relatively flat land and low elevation. The dynamics of natural events, such as global warming, high-intensity rainfall, and river sedimentation, as well as human activities, such as land conversion, housing construction on the riverbank, and the lack of flood control infrastructure are increasing the risk of flooding (Authority, 2015). The National Disaster Management Authority categorizes floods into the following: coastal flooding, river flooding, and flash flooding. Coastal flooding occurs because of high tides submerging the land, while river flooding occurs because of the overcapacity of rivers; and flash flooding (inundation) occurs because of inadequate drainage capacity or poor drainage conditions (Government, 2019).

Flood and inundation risks faced by each catchment area are affected by many factors, such as the individual characteristics of the actual storm events, drainage and pumping capacity, system failure, levee height, water surface elevation, and other factors. Each individual or combination of these aspects may have different effects based on the characteristics and sensitivities of the catchment areas. High-intensity rainfall and climate change in rapid growth areas increase the frequency of urban drainage failure (Ngamalieu-Nengoue, Iglesias-Rey, Martínez-Solano, Mora-Meliá, \& Valderrama, 2019; Yongchao Zhou, 2019).

Poor urban drainage physical conditions greatly affect the performance of the entire drainage system. Poor drainage system conditions could interfere with water flow and cause flooding. Flood inundation in urban areas may lead to direct losses to the residents and their properties and indirect losses in the form of interruption to their daily activities. Inundations also leave behind a dirty and muddy environment, ruin the local aesthetics, and can be a breeding ground for various diseases (Suripin, 2004; Yazdi, 2017). Urban drainage system maintenance is crucial in ensuring that the drainage system is in good physical condition and to guarantee that the drainage system works properly. The dynamics of socioeconomic activities and development in the city significantly fortify or degrade urban drainage condition (Jonatan Zischg, 2018).

Various types of flood and inundation risk reduction activities involving multiple stakeholders have been performed on a massive scale in several regions. One activity that is generally applied in high-risk inundation areas is drainage maintenance that is carried out through various programs. To obtain clear results, this research focuses on all drainage maintenance activities performed in areas categorized as inundation prone.

The study site was in Tegal, a small coastal city located in the northern part of Java with a $7.5 \mathrm{~km}$ coastline. The city of Tegal was chosen as the research location because flooding and inundation occur annually in this area. Massive drainage treatment and maintenance programs have been implemented by the local government in the last five years; consequently, cases of flooding in the area are gradually decreasing, but they still persist every year. Government efforts to develop a good drainage system are not significant enough to completely overcome flood and inundation problems. The objective of this research is to observe the implementation of drainage maintenance and its impact on inundation in the research area. This research also analyzes the role of each activity on inundation reduction.

\section{Methodology}

The primary objective of this research is to analyze the general characteristics and the impact of drainage maintenance activity in inundation areas and to consider future inundation treatment.

\subsection{Data Collection}

Tegal (Figure 1) is a small coastal city located in the northern part of Java, Indonesia, covering an area of $39.68 \mathrm{~km}^{2}$ with a total population of 276,734 in 2018. Three large rivers (Kali Gangsa, Kali Ketiwon, and Kali Gung) and two smalls rivers (Kali Kemiri and Kali Sibelius) flow through the Tegal area (Government, 2019). The city is located at a low elevation of 0-3 $\mathrm{m}$ above sea level and experiences highintensity rainfall; thus, more than half of the area is categorized as having a moderate to high flood risk (Authority, 2015). 
Moreover, based on the 2015 vulnerability index data released by the Ministry of Environment and Forestry, two villages in the area are categorized as high disaster risk with low levels of adaptation to climate change; therefore, direct action is needed to improve climate change adaptation in the region. Thirteen villages are categorized as moderate disaster risk, and the rest are categorized as low disaster risk. However, based on the Tegal hazard map published by the Planning Agency, 18 of 27 villages in Tegal are categorized as having a moderate to high risk of flooding.

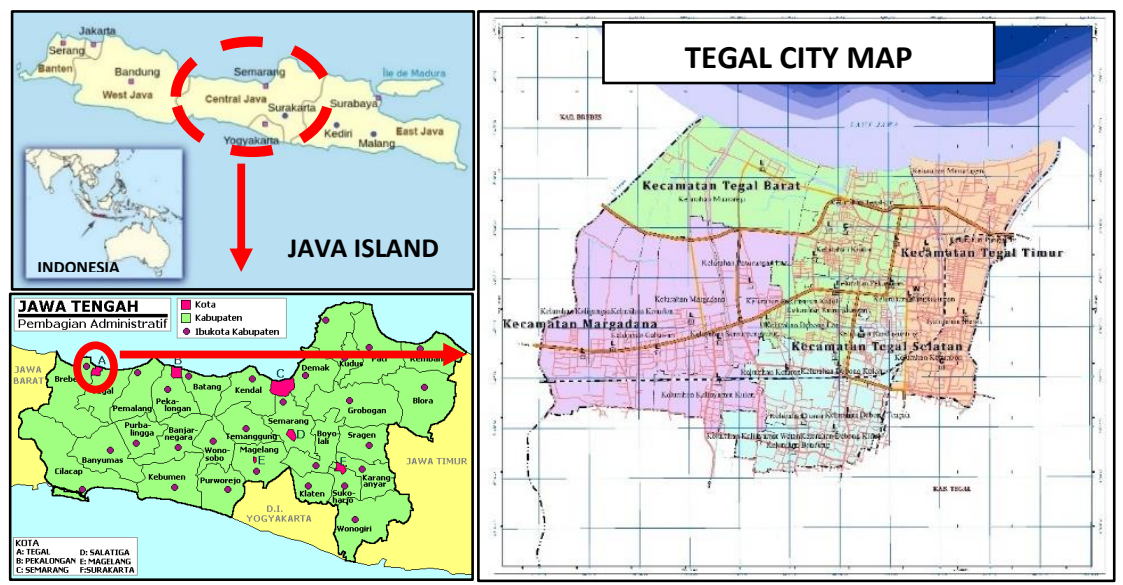

Figure 1. Location of Study Area (Government, 2019).

Interviews and field surveys regarding drainage conditions, inundation areas, and the treatments applied to the drainage channel were conducted in August 2019 and March 2020. These interviews were conducted to the local government's officials and communities who reside near the inundation areas. Secondary data were collected from various sources, namely the Public Works Agency, Planning Agency, Village Government, and the Ministry of Public Works and Housing.

\subsection{Research Method}

To analyze drainage maintenance activities and the impacts of drainage conditions and inundation reduction, the analyses were divided into two parts, i.e., technical and social analyses.

Table 1: Analysis Method.

\begin{tabular}{lll}
\hline \multicolumn{1}{c}{ Technical Analysis } & \multicolumn{1}{c}{ Social Analysis } \\
\hline - Water Runoff in Urban Catchment Area & - Dissemination of Drainage Maintenance Activity \\
- Drainage Capacity & - Drainage Cleaning Frequency \\
- Drainage Condition & - Community Participation \\
- Normalization, Rehabilitation, and New Channel & \\
$\quad$ Development & \\
- Inundation reduction & \\
\hline
\end{tabular}

The catchment area in each inundation location is divided into sub-catchment areas, which follows the water runoff pattern in the system and analyzed using GIS program. The Rational Method was used to adjust the flow rate according to the following formula (Davies, 2000):

$$
\boldsymbol{Q}=2.78 \mathrm{CiA}
$$

$\boldsymbol{Q} \quad$ maximum flow rate $(\mathrm{l} / \mathrm{s})$

$\boldsymbol{i} \quad$ rainfall intensity $(\mathrm{mm} / \mathrm{h})$

A catchment area (ha)

The water runoff calculation was compared to the drainage capacity calculation. The comparison result was analyzed using a GIS map to produce a high probability prediction of inundation in a location as a result of water overflow. Because urban drainage channels in Tegal are mostly open channels, the following equation was employed to calculate drainage capacity (Davies, 2000): 


$$
\mathcal{Q}=\frac{1}{n} R^{\frac{2}{3}} S_{o}^{\frac{1}{2}} \cdot A
$$

n Manning's Roughness coefficient $\left(m^{-\frac{1}{3}} s\right)$

So bed slope

A wet cross-sectional area

Considering that no specific regulation or standard of assessment on drainage channel and network condition exists, the evaluation of drainage channel conditions shall refer to the Ministry of Public Works and Housing Regulation No. 32 of 2007 on Irrigation Channel and the Ministry of Public Works and Housing Circular Letter No. 02 of 2011 on Swamp Reclamation.

Table 2: Risk Scale Index Determination Based on drainage Physical Condition and Sedimentation Level.

\begin{tabular}{|c|c|c|c|c|c|c|}
\hline Index & Physical Condition & $\begin{array}{l}\text { Damage } \\
\text { Level (\%) }\end{array}$ & $\begin{array}{l}\text { Sedimentation } \\
\text { Level (\%) }\end{array}$ & $\begin{array}{c}\text { Function } \\
\text { (\%) }\end{array}$ & $\begin{array}{l}\text { Condition } \\
\text { State }\end{array}$ & Risk Scale \\
\hline 1 & $\begin{array}{l}\text { Good structural condition, no } \\
\text { significant damage }\end{array}$ & $<10$ & 0 & $76-100$ & Good & $1-2$ (Very low) \\
\hline 2 & $\begin{array}{l}\text { Medium structural condition with } \\
\text { some damages but fully functional }\end{array}$ & $10-20$ & $1-25$ & $51-75$ & Fair & $3-4$ (Low) \\
\hline 3 & $\begin{array}{l}\text { Severe damage with interrupted } \\
\text { channel function }\end{array}$ & $21-40$ & $26-50$ & $26-50$ & $\begin{array}{l}\text { Lightly } \\
\text { damaged }\end{array}$ & $5-6$ (Medium) \\
\hline 4 & $\begin{array}{l}\text { Heavy damage that reduces } \\
\text { channel capacity }\end{array}$ & $>40$ & $51-75$ & $1-25$ & $\begin{array}{l}\text { Heavily } \\
\text { damaged }\end{array}$ & $7-8$ (High) \\
\hline 5 & $\begin{array}{l}\text { Total damage and total channel } \\
\text { malfunction }\end{array}$ & $>70$ & $76-100$ & 0 & Broken & $\begin{array}{l}9-10 \text { (Very } \\
\text { high) }\end{array}$ \\
\hline
\end{tabular}

Source: (Faiz Isma, 2018) and Channel Condition Criteria in Ministry of Public Works and Housing Regulation Number 32 of 2007 on Irrigation Channel

Each drainage condition requires a specific treatment depending on the damage and channel function.

Table 3: Recommendation Treatment.

\begin{tabular}{|l|l|l|l|}
\hline Index & Inundation Depth & Function (\%) & Treatment Recommendation \\
\hline 1 & $<0.3 \mathrm{~m}$ & $76-100$ & Routine Maintenance \\
\hline 2 & $0.3-0.5 \mathrm{~m}$ & $51-75$ & Periodic Maintenance \\
\hline 3 & $0.5-1 \mathrm{~m}$ & $26-50$ & Rehabilitation (Channel Repair) \\
\hline 4 & $1-3 \mathrm{~m}$ & $1-25$ & Rehabilitation (Channel Replacement) \\
\hline 5 & $>3 \mathrm{~m}$ & 0 & Channel New Development \\
\hline
\end{tabular}

Source: (Faiz Isma, 2018).

The inundation risk map is determined by overlaying the drainage sufficiency, elevation, and slope maps. The spatial analysis involves a series of geographical modeling processes that use maps and imagery, computational analysis, and geographical patterns to produce advanced predictive modeling. The two methods commonly used in spatial analysis are the feature overlay (overlaying points, lines, or polygons) and raster overlay (Esri Press Team, 2018). Geographic Information System (GIS) overlay analysis operation focuses on map layers that can express the global relationship among those layers, while raster overlay references map layers with the same geographic location, making it well suited to compile the characteristics of numerous layers into a single layer (Tiede, 2014). By comparing the inundation risk map before and after the drainage maintenance which is carried out with the maintenance activity overlay, the effectiveness of maintenance activity could be examined. The social analysis determines the effect of community behaviors on drainage conditions. 

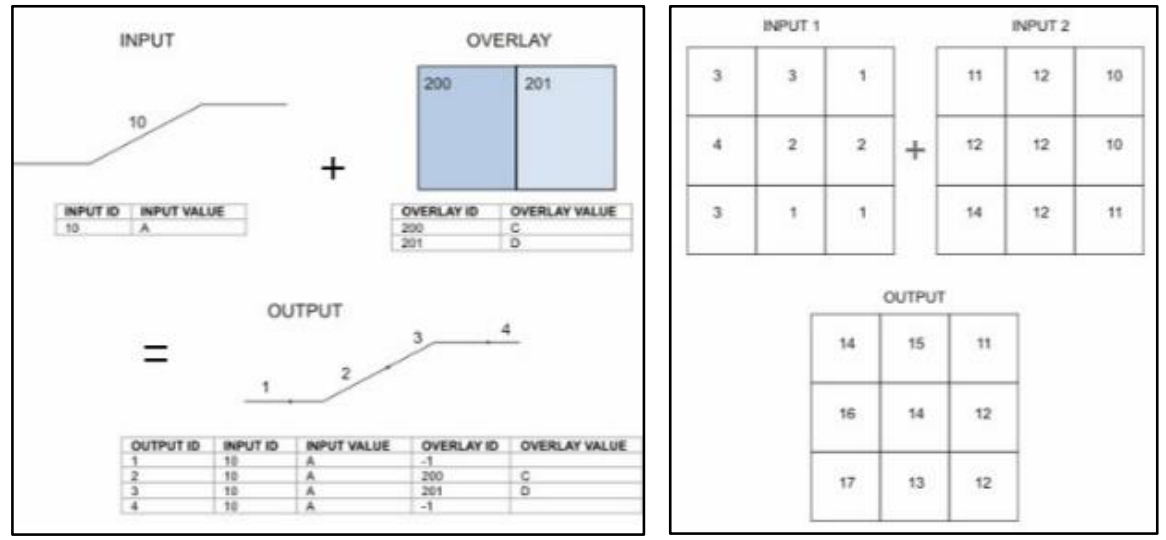

Figure 2. Feature Overlay (Left) and Raster Overlay (Right). Source: (Esri Press Team, 2018).

\section{Results and Discussions}

\subsection{Inundation Risk Area}

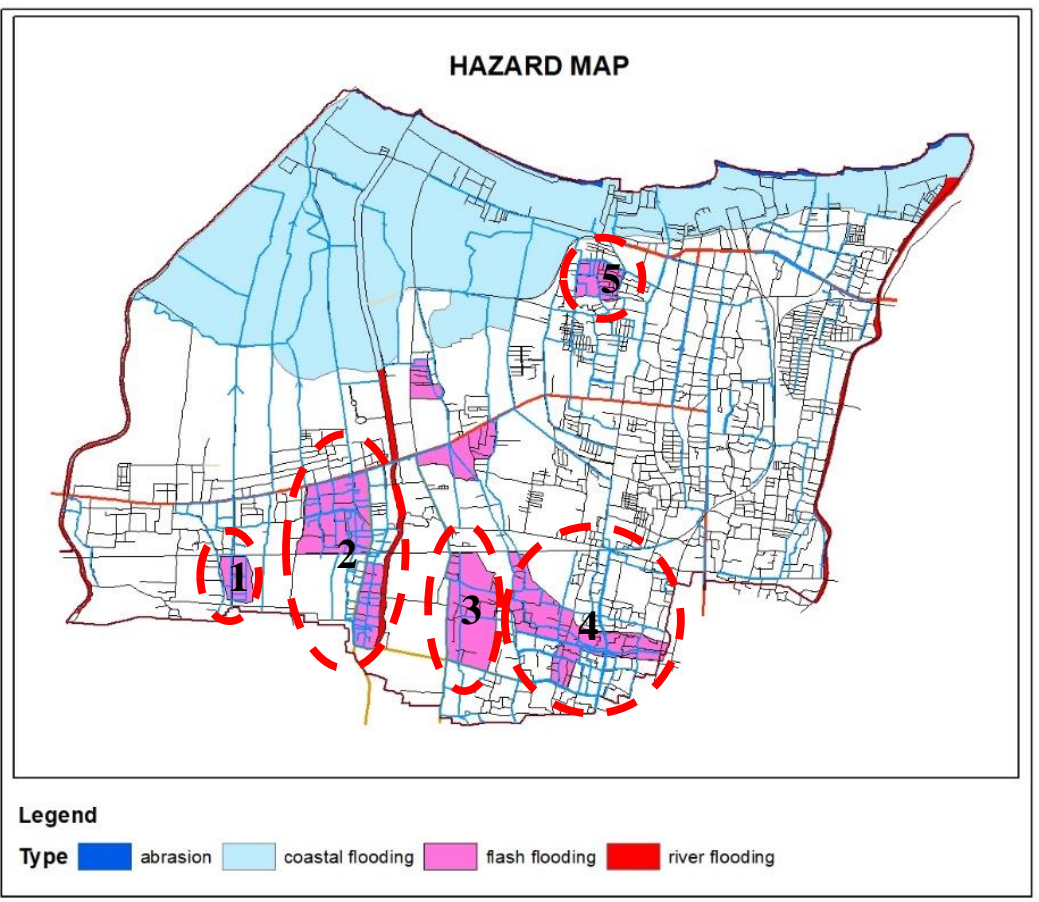

Figure 3. Hazard Map and Inundation-Prone Locations in Tegal.

Eight locations in Tegal are categorized as flash flood-prone areas affected by stormwater (Figure 3). Based on the elevation and inundation map analysis, three out of the eight inundation areas are located at sites that are lower than their surroundings. Rainwater cannot move out of the low-elevation areas; therefore, it increases the vulnerability and the scale of inundation. Moreover, Tegal is categorized as a highly flood-prone area because of the additional volume of water flowing in from Tegal Regency. At the end of 2018, the area of Tegal affected by coastal and flash flooding reached $100.39 \mathrm{Ha}$ (2.53\%). Reduced water catchment areas, the high sediment levels, and the lack of existing channel integration that connects Tegal are the additional detrimental factors. In the first quarter of 2019, moderate-intensity rainfall inundated an approximately 50.59 hectares of land (12.84\%) (Government, 2019).

To reduce the risk, the local government has already implemented several programs, including drainage channel maintenance, retention pond construction, and water pump procurement. The result of the flood management efforts has been positive, as seen in several locations, while others have experienced no significant changes. A detailed maintenance and inundation area analysis was performed in six of the eight locations. Because the main program was not actively implemented in the other two locations, no significant reduction in the level of inundation was apparent in these two areas. The first 
analysis was performed for Cabawan village, in the western part of the city. The second analysis consisted of two flood-prone areas that share a watershed. The third and fourth inundation areas are located in the eastern side of the second analysis area. The fifth is located in the northern side of the city near the sea.

\subsection{Drainage Maintenance Activity}

From 2016-2019, frequent types of drainage maintenance activities were carried out in Tegal under numerous programs by governments at the central, provincial, city, and local levels. Other stakeholders, including corporations implementing their corporate social responsibility (CSR) programs and the village community also actively participated in the process. A detailed illustration of the urban drainage channel maintenance activity is presented in Table 13. The black font color denotes the maintenance programs that were used in inundation area analysis, and the red color indicates inadequate maintenance programs that did not have a significant influence on drainage conditions and inundation reduction in the chosen areas.

Table 4: Drainage Maintenance Activity.

\begin{tabular}{|l|c|c|c|c|}
\hline Stakeholders & $\begin{array}{c}\text { Routine } \\
\text { Maintenance }\end{array}$ & $\begin{array}{c}\text { Periodic } \\
\text { Maintenance }\end{array}$ & Rehabilitation & $\begin{array}{c}\text { Special } \\
\text { Maintenance }\end{array}$ \\
\hline $\begin{array}{l}\text { Central } \\
\text { Government }\end{array}$ & & River Normalization & $\begin{array}{c}\text { Kotaku (Housing Area Upgrading) } \\
- \text { NUSP BDI Program }\end{array}$ & $\begin{array}{c}\text { Coastal Drainage } \\
\text { Development }\end{array}$ \\
\hline $\begin{array}{l}\text { Province } \\
\text { Government }\end{array}$ & $\begin{array}{c}\text { Bio pore } \\
\text { program to } \\
\text { City } \\
\text { Government } \\
\text { reduce drainage } \\
\text { load (DLH) }\end{array}$ & $\begin{array}{l}\text { - Irrigation channel } \\
\text { maintenance } \\
\text { Inundation } \\
\text { reduction }\end{array}$ & $\begin{array}{l}- \text { Irrigation channel maintenance } \\
\text { Inundation reduction } \\
\text { Collector Channel Rehabilitation } \\
\text { (DPU Cipta Karya) }\end{array}$ & $\begin{array}{c}\text { Retention Pond, } \\
\text { Water pump and } \\
\text { Sluice Gate }\end{array}$ \\
\hline Village & $\begin{array}{c}\text { APIK program } \\
\text { Clean the } \\
\text { channel }\end{array}$ & & & \\
\hline
\end{tabular}

Source: Interview with Public Works Agency, Planning Agency, and Housing Agency of Tegal

\subsubsection{Routine Maintenance}

Periodic urban drainage channel maintenance is carried out by the city government through the bio-pore maintenance and monitoring programs, and by the village community through an urban drainage cleaning activity. Coordinated by the environmental agency of Tegal, a bio-pore maintenance program is intended to increase the quantity of water catchment areas to reduce water runoff. The water load in the drainage channel decreases in line with a drop in the volume of the runoff. Unfortunately, this program is still in its early stages and does not show significant results, because the number of bio pores remains low. The results of the questionnaire pertaining to the program reveal that the basic bio-pore data is also unavailable. Thus, this program was not included in the analysis.
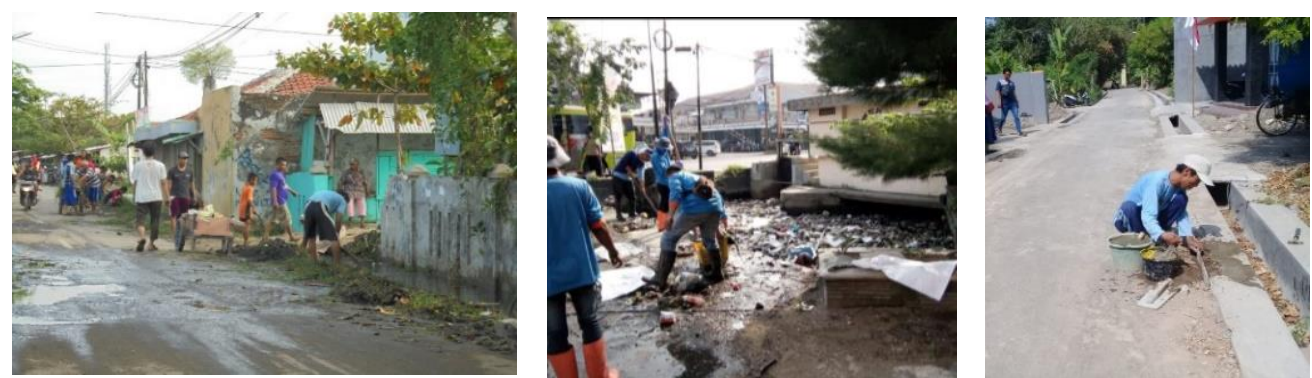

Figure 4. Routine Maintenance by the Community (left), by Local Government (middle) and by Drainage Repair Worker.

Tertiary and neighborhood drainage cleaning programs were initiated by the local and village governments and performed by the village community. Dissemination of public information regarding the importance of urban drainage channel maintenance is regularly provided by the local governments, especially before the rainy season. The local government constantly urges the community to actively participate in the periodic drainage cleaning activities to reduce flooding. However, depending on the community characteristics, each village responds differently regarding this request. 


\subsubsection{Periodic Maintenance}

Periodic maintenance is conducted by the provincial government to bring about normalization of the riverbank and by the local government under an irrigation channel maintenance program and inundation reduction program. In 2016-2019, no riverbank normalization activities were conducted by the provincial government because Tegal was considered to have a lower risk than the other 32 regions. The fact of the matter is that the provincial government prioritizes actions in cities with a higher risk of inundation, landslides, and earthquakes. However, because river sediment cleaning is not the responsibility of the local government, they cannot, on their own, act on riverbank treatment.

The local government, through the Water Division of the Public Works Agency, directed a periodic maintenance in irrigation, primary and secondary channels for urban drainage cleaning, channel rehabilitation, and other treatments i.e., sluice gate maintenance and demolition of illegal buildings that obstruct the function of urban drainage. The detailed periodic maintenance activities conducted by the water division of the Tegal local government are presented in Table 5.

Table 5: Periodic and Special Maintenance Activities Conducted by Local Government from 2017 to 2019.

\begin{tabular}{|c|c|r|r|r|r|}
\hline Program & Year & $\begin{array}{c}\text { Drainage } \\
\text { Cleaning } \mathbf{( m )}\end{array}$ & $\begin{array}{c}\text { Drainage } \\
\text { Repair } \mathbf{( m )}\end{array}$ & $\begin{array}{c}\text { Sluice Gate } \\
\text { Repair (unit) }\end{array}$ & $\begin{array}{c}\text { Pump } \\
\text { Establishment }\end{array}$ \\
\hline \multirow{6}{*}{2017} & 11722 & 401 & 2 & 0 \\
\hline & 2018 & 16712 & 7156 & 0 & 0 \\
\hline & 2019 & 9495 & 137 & 9 & 0 \\
\hline & 2017 & 15017 & 625 & 0 & 0 \\
\hline & 2018 & 0 & 514 & 3 & 0 \\
\hline
\end{tabular}

\subsubsection{Rehabilitation}

Rehabilitation of an urban drainage channel is performed by two methods: drainage channel repair and drainage channel replacement. In addition to the channel rehabilitation implemented by the local government (mentioned in Table 3), other rehabilitation activities are conducted by the central and village governments. Most of the drainage channel replacement is carried out under the Kotaku (housing area upgrade) program by the central government in dense neighborhoods to reduce slums. Because no channel replacement was identified in the chosen area of analysis, further discussion will only focus on drainage channel repair.

One of the special programs initiated by some local governments in Central Java Province is the Akselerasi Pembangunan Infrastruktur Kelurahan (Accelerated Urban Village Infrastructure Development (APIK)) program. Tegal Regulation No. 4 of 2016 (regarding the APIK Program Implementation Instructions) defines APIK as a community empowerment program to accelerate the development of basic infrastructure facilities for the area to achieve a clean and healthy residential environment. The program is carried out by the village government under the auspices of the local government through a housing upgrading program.

\subsubsection{Special Maintenance}

Special urban drainage maintenance activities were implemented by the central government under the Coastal Settlement Development Program to reduce slums in coastal settlement neighborhoods and by the local governments through various tailor made programs, i.e., installing sluice gates, water pumps, and retention ponds treatments that follows the unique character of each watershed. Special maintenance programs that have been applied are discussed in detail in the following inundation area analysis.

\subsubsection{Urban Drainage System Problems}

According to the result of the interviews conducted with the local government, urban drainage maintenance activity problems in Tegal are classified as social and technical problems. Technical problems are issues correlated with the ability of the urban drainage network to perform its function of discharging rainwater from the mainland; meanwhile, social problems are related to administrative issues and the behavior of the population towards urban drainage. 


\section{Social Problems:}

Community Behavior

Community behavior toward an urban drainage system has a significant influence on drainage network optimization, especially regarding waste and sediment accumulation. Littering in the drainage channel eventually clogs the channel with garbage and disrupts drainage channel performance. Negative community behavior in urban drainage channel has to change, because how the community behaves ultimately will affect drainage conditions, and the community plays a critical role in performing tertiary urban drainage cleaning.

- Law Enforcement

There are some regulations related to building development from the join central and local government's regulations that prohibit construction over urban drainage channels. Furthermore, the city spatial planning (RTRW) and city development planning (RPJMD) documents provide building development guidelines that determine where buildings can be constructed. However, because of the lack of stringent punitive measures for people who break the rules, noncompliance is considered as somewhat normal. People commonly set up shops or trades over the top of the drainage channel on the side road. Moreover, the main drainage channel located far from the main road, which usually has bigger dimensions, is used as a makeshift kitchen and washroom. To improve the effectiveness of drainage maintenance, strict law enforcement is urgently needed. A scheme of reward and punishment may also be implemented to increase community awareness in law enforcement attempt regarding drainage maintenance activity.

- Institution Synchronization

Institutional problems grow into classical problems in many spaces and aspects. The urban drainage problem grows more complex, as the system collects water from upstream through several districts before finally reaching downstream. The division of authority and responsibilities without a solid coordination between the relevant institutions will exacerbate an already ineffective drainage maintenance and drainage control, especially in the river and primary channels.

- Urban Channel Data Sufficiency

One social obstacle in the drainage maintenance effort is the unavailability of detailed data on the overall urban drainage network. Insufficient urban drainage system data will lead to problems in identifying channel conditions and maintenance planning arrangements. The local government has already taken several measures to solve the data sufficiency problem by collecting urban drainage data since 2019. Because the urban drainage system is rather complex, the data collection process is still ongoing in 2020.

\section{Technical Problems}

\section{- Channel Dimension}

Most of the primary and secondary channels in Tegal are old channels built before most of the settlement areas were developed. Land conversion from rice fields and mixed plantations into settlement areas increases the volume of water runoff. Without channeldimension enhancement, inundation reduction is difficult to achieve.

- Elevation

Some areas near the sea and the river tend to have a lower elevation with a mild slope, which slows the velocity of water flow. Water elevation in some areas is also higher than in the mainland. Ordinary urban drainage treatment is not sufficient to eliminate the recurring inundation and special treatments such as water pumps installation and sluice gates construction should be implemented to ensure that the drainage network functions properly.

- $\quad$ Combined Drainage System

Sediment creation in a combined drainage system is relatively faster than in a separate drainage system and can easily overwhelms drainage cleaning performance. Therefore, sediment measurements in combined drainage channels are consistently high. Drainage cleaning action needs to be accelerated to offset the sediment.

- Vegetation Growth Close to Rice Fields, Farms, and Mixed Plantations In addition to carrying stormwater and wastewater, urban drainage transports excess irrigation from fields that usually contain seeds. Vegetation usually flourishes near rice fields, 
farms, and mixed plantations and it eventually interferes with drainage channel performance. Therefore, periodic cleaning should be conducted in those channels.

- Urban Drainage Location

In the dense settlement area, the drainage channel is usually located between two houses or buildings, and some even located under buildings; thus, the drainage is relatively untouched and difficult to observe and maintain.

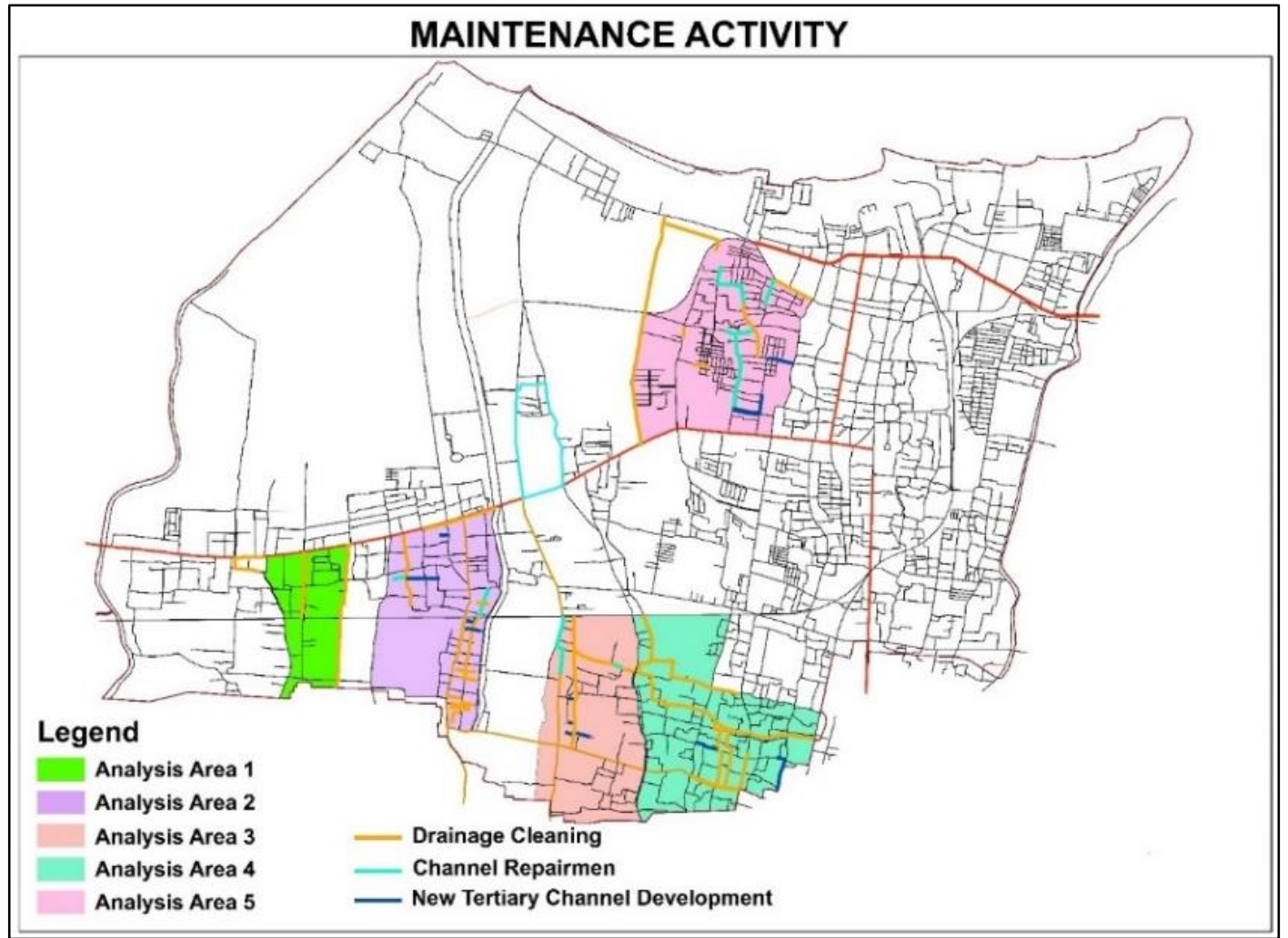

Figure 5. Drainage Maintenance Activities in Tegal.

\subsection{Technical Analysis}

Technical analysis was conducted by comparing water runoff and drainage capacity in each chosen inundation area followed by drainage maintenance and inundation reduction analysis.

3.3.1. Water Runoff and Drainage Capacity Comparison

a. Cabawan Village Analysis Area (Analysis Area 1)

Table 6: Cabawan Drainage Capacity Calculation Result.

\begin{tabular}{|c|c|c|c|c|c|c|}
\hline \multirow[b]{2}{*}{$\begin{array}{c}\text { Catchment } \\
\text { Area }\end{array}$} & \multicolumn{3}{|c|}{ Water Runoff } & \multicolumn{3}{|c|}{ Drainage Capacity } \\
\hline & $\begin{array}{c}\text { 2-years } \\
\text { Return } \\
\text { Period (L/s) }\end{array}$ & $\begin{array}{c}\text { 5-years } \\
\text { Return } \\
\text { Period (L/s) }\end{array}$ & $\begin{array}{c}\text { 10-ears } \\
\text { Return } \\
\text { Period (L/s) }\end{array}$ & $\begin{array}{c}\text { Current } \\
\text { Drainage } \\
\text { Capacity (L/s) }\end{array}$ & $\begin{array}{c}\text { Drainage Capacity } \\
\text { Without Sediment } \\
(\mathrm{L} / \mathrm{s})\end{array}$ & $\begin{array}{c}\text { Planned } \\
\text { Drainage } \\
\text { Capacity (L/s) }\end{array}$ \\
\hline Subsystem 1 & 0.296 & 0.405 & 0.499 & 23.348 & 40.442 & 31.577 \\
\hline Subsystem 2 & 1.471 & 2.011 & 2.476 & 2.809 & 4.992 & 12.133 \\
\hline Subsystem 3 & 0.445 & 0.608 & 0.749 & 1.081 & 1.836 & 3.266 \\
\hline Subsystem 4 & 1.497 & 2.048 & 2.521 & 5.548 & 9.911 & 17.523 \\
\hline & 3.709 & 5.072 & 6.246 & 26.881 & 46.777 & 31.577 \\
\hline Subsystem 5 & 1.285 & 1.757 & 2.163 & 6.184 & 10.038 & 16.160 \\
\hline Subsystem 6 & 1.763 & 2.410 & 2.968 & 1.324 & 2.169 & 1.876 \\
\hline Subsystem 7 & 1.208 & 1.652 & 2.034 & 1.324 & 2.169 & 1.876 \\
\hline Subsystem 8 & 1.370 & 1.873 & 2.306 & 7.185 & 12.542 & 15.061 \\
\hline Subsystem 9 & 2.121 & 2.900 & 3.570 & 1.324 & 2.144 & 1.876 \\
\hline & 11.456 & 15.664 & 19.288 & 34.656 & 66.565 & 31.577 \\
\hline
\end{tabular}


The result of the channel capacity calculation shows that the current channel capacity in subsystems 6 and 9 is smaller than the required capacity for the 6-hours rainfall analysis of the 2-year return period. This condition makes the possibility of inundation high in both areas. When the channel is clear without sediment, the increase of the channel capacity becomes more prominent than the required capacity. The inundation risk determined by the urban drainage network before treatment is shown in Table 6.

Before drainage maintenance treatment was conducted, almost all the areas were categorized as high-risk inundation with the 4th level risk index displayed in orange on the map (Figure 80). Because this location has a high elevation $(9 \mathrm{~m}$ ) with steep slopes, drainage capacity has a greater impact on the formation of inundation. The maintenance activities in the inundated area were focused on normalizing the secondary and irrigation channels. No rehabilitation or new channel construction programs were applied in this area. In 2017 and 2018, around 1,228 m of irrigation channel was normalized through the inundation reduction program carried out by the Water Division of Public Works Agency. However, although maintenance activities were focused on the secondary channel, the average condition of the secondary channel (54.87\%) was slightly smaller than the average condition of the tertiary channel (up to $58.91 \%)$.

\section{b. Margadana, Sumurpanggang and Kalinyamat Kulon Village Analysis Area (Analysis Area 2)}

On the Tegal hazard map, the subsystem 1, 2, and 3 are designated as risky areas, except for the subsystem 4 , which is not categorized as a risk area. Although the drainage capacity in the subsystem 1 and 3 is categorized as a risk area, their drainage capacities are larger than the water runoff. In the subsystem 4, the drainage capacity is not sufficient to accommodate the overflow. As a result, annual inundations continue to occur in this area. The maximum drainage capacity in subsystem 2 is larger than the runoff capacity from the 10-year return period calculation. However, because of sedimentation, the current capacity of the secondary channel is lower than the required capacity. In 2020, inundation only occurred in the subsystem 4.

Table 7: Margadana, Sumurpanggang and Kalinyamat Kulon Drainage Capacity Calculation Result.

\begin{tabular}{|c|c|c|c|c|c|c|}
\hline \multirow[b]{2}{*}{$\begin{array}{c}\text { Catchment } \\
\text { Area }\end{array}$} & \multicolumn{3}{|c|}{ Capacity Requirement } & \multicolumn{3}{|c|}{ Drainage Capacity } \\
\hline & $\begin{array}{c}\text { 2-years } \\
\text { Return } \\
\text { Period (L/s) }\end{array}$ & $\begin{array}{c}5 \text {-years } \\
\text { Return } \\
\text { Period }(L / s)\end{array}$ & $\begin{array}{c}\text { 10-years } \\
\text { Return } \\
\text { Period }(\mathrm{L} / \mathrm{s})\end{array}$ & $\begin{array}{c}\text { Current } \\
\text { Drainage } \\
\text { Capacity (L/s) }\end{array}$ & $\begin{array}{c}\text { Drainage Capacity } \\
\text { Without Sediment } \\
\text { (L/s) }\end{array}$ & $\begin{array}{c}\text { Planned } \\
\text { Drainage } \\
\text { Capacity (L/s) }\end{array}$ \\
\hline Subsystem 1 & 4.237 & 5.794 & 7.134 & 34.727 & 49.417 & 34.264 \\
\hline Subsystem 2 & 2.296 & 3.140 & 3.866 & 1.414 & 8.446 & 0.801 \\
\hline Subsystem 3 & 2.402 & 3.284 & 4.044 & 28.993 & 43.072 & 46.493 \\
\hline \multirow[t]{2}{*}{ Subsystem 4} & 2.257 & 3.086 & 3.800 & 0.115 & 0.212 & 0.261 \\
\hline & 11.193 & 15.304 & 18.845 & 34.727 & 49.417 & 34.264 \\
\hline Subsystem 5 & 2.429 & 3.321 & 4.090 & 3.957 & 5.118 & 5.118 \\
\hline Subsystem 6 & 2.910 & 3.978 & 4.899 & 9.425 & 19.046 & 34.583 \\
\hline \multirow[t]{3}{*}{ Subsystem 7} & 2.388 & 3.265 & 4.021 & 2.702 & 3.301 & 29.892 \\
\hline & & & & \multicolumn{3}{|c|}{ Water Pump 1 × $250 \mathrm{~L} / \mathrm{s}(0.25 \mathrm{~m} 3 / \mathrm{s})$} \\
\hline & 13.6217 & 18.6256 & 22.9345 & 12.15109252 & 26.93315841 & 26.93316 \\
\hline
\end{tabular}

In the southern side, the catchment area is divided into subsystems 5, 6 and 7. Most of the water runoff collected in the subsystem 6 and 7 empties into the river through a secondary channel located alongside the railroad tracks to the north. The drainage capacity in subsystem 6 is higher than the capacity required, whereas the maximum capacity in subsystem 7 is only capable of accommodating the intensity of 6-hours rainfall in a five-year return period. However, the principal problem is the low elevation. The sluice gate prevents water flows from the river to the residential area. The gate is supposed to close, and the water pump should engage as the water level rises. The problem occurs in the rainy season as the river water and discharged water from the land reach their highest levels at the same time. To discharge rainwater from the settlement area to the river, a water pump with a capacity of $250 \mathrm{~L} / \mathrm{s}$ is used. Compared to the overflow calculation, this pump capacity is simply too small to accommodate all the rainwater in the catchment areas 6 and 7. The drainage maintenance activities applied in Kalinyamat Kulon, Sumurpanggang, and Margadana village are shown in Table 8. 
Table 8: Summary of Maintenance Activities in Margadana, Sumurpanggang and Kalinyamat Kulon Village Analysis Area

\begin{tabular}{|c|c|c|c|c|c|}
\hline \multirow[b]{2}{*}{ Channel } & \multirow[b]{2}{*}{$\begin{array}{c}\text { Normalization } \\
(\mathrm{m})\end{array}$} & \multirow[b]{2}{*}{$\begin{array}{l}\text { Rehabilitation } \\
\text { (m) }\end{array}$} & \multirow{2}{*}{$\begin{array}{c}\text { New } \\
\text { Development } \\
\text { (m) }\end{array}$} & \multicolumn{2}{|c|}{ Drainage Average Condition } \\
\hline & & & & $\begin{array}{c}\text { Without } \\
\text { Maintenance }(\mathrm{m})\end{array}$ & $\begin{array}{l}\text { With Maintenance } \\
(\mathrm{m})\end{array}$ \\
\hline Primary & 0 & 0 & 0 & 55.36 & $\begin{array}{c}\text { no maintenance } \\
\text { activity }\end{array}$ \\
\hline Secondary & 2905 & 226 & 0 & 68.63 & 70.55 \\
\hline Tertiary & 1880 & 139 & 644 & 62.16 & 64.85 \\
\hline
\end{tabular}

None of the drainage channels in this location is categorized as the primary channel, and the water from the secondary channel flows directly into the river. The average condition of the secondary drainage channel after maintenance is $70.55 \%$, which is only $2 \%$ higher than the drainage condition without maintenance. This number also appears in the tertiary drainage channel, where the capacity increases slightly from $62.16 \%$ to $64.85 \%$. In general, maintenance activities do not have a significant impact on the conditions of secondary and tertiary drainage. However, in the location where a new drainage channel was constructed, connectivity between tertiary drainage is established, thereby reducing the extent and duration of the inundation.

Although the installation of water pump is able to reduce the inundation area from 54-10 ha and 24-10 ha in the northern and southern sides of the railroad tracks respectively, the pump capacity needs to be increased to solve the inundation problem in this area once and for all.

\section{c. Tunon, Keturen, Bandung, Kalinyamat Wetan and Kalinyamat Kulon Village Analysis Area (Analysis Area 3)}

The results of drainage capacity calculation of the analysis area show that the volume of water runoff is larger than the maximum drainage capacity in all catchment areas, which lead to inundation in all of the analyzed areas. The absence of tertiary channels in the subsystems 4 and 5 causes rainwater to flow into the same channel. The small capacity of the channel generates water overflow that becomes an inundation with the onset of rain.

Table 9. Tunon, Keturen Bandung, Kalinyamat Wetan and Kalinyamat Kulon Village Drainage Capacity Calculation Result

\begin{tabular}{|c|c|c|c|c|c|c|}
\hline \multirow[b]{2}{*}{$\begin{array}{l}\text { Catchment } \\
\text { Area }\end{array}$} & \multicolumn{3}{|c|}{ Capacity Requirement } & \multicolumn{3}{|c|}{ Drainage Capacity } \\
\hline & $\begin{array}{c}2 \text { Years } \\
\text { Return } \\
\text { Period (L/s) }\end{array}$ & $\begin{array}{c}5 \text { Years } \\
\text { Return } \\
\text { Period (L/s) }\end{array}$ & $\begin{array}{c}10 \text { Years } \\
\text { Return } \\
\text { Period (L/s) }\end{array}$ & $\begin{array}{c}\text { Maximum } \\
\text { Drainage } \\
\text { Capacity }(\mathrm{L} / \mathrm{s})\end{array}$ & $\begin{array}{c}\text { Drainage Capacity } \\
\text { Without Sediment (L/s) }\end{array}$ & $\begin{array}{c}\text { Planned } \\
\text { Drainage } \\
\text { Capacity (L/s) }\end{array}$ \\
\hline \multirow[t]{3}{*}{ Subsystem 1} & 2.724 & 3.725 & 4.586 & 0.976 & 1.287 & 1.287 \\
\hline & & & & 0.374 & 0.559 & 0.489 \\
\hline & & & & 2.020 & 3.050 & 3.050 \\
\hline Subsystem 2 & 2.501 & 3.420 & 4.211 & 1.444 & 1.970 & 3.410 \\
\hline Subsystem 3 & 1.723 & 2.355 & 2.900 & 1.276 & 1.591 & 2.2326209 \\
\hline Subsystem 4 & 0.981 & 1.342 & 1.652 & & & \\
\hline \multirow[t]{3}{*}{ Subsystem 5} & 1.904 & 2.603 & 3.205 & & & \\
\hline & 2.885 & 3.944 & 4.857 & 1.843 & 2.154 & 2.154 \\
\hline & 9.832 & 13.444 & 16.554 & 37.452 & 63.876 & 136.488 \\
\hline
\end{tabular}

Table 10 illustrates that normalization activities focused on the primary channels and were applied to $2050 \mathrm{~m}$ of the primary channels and, therefore, to all the primary channels in the analysis area. Drainage clean-up was applied to $577 \mathrm{~m}$ of secondary channel and $100 \mathrm{~m}$ of irrigation channel. Channel repairs are concentrated on the irrigation channels and new developments are dedicated to the tertiary channels.

Table 10. Summary of Maintenance Activities in of Tunon, Keturen, Bandung, Kalinyamat Wetan and Kalinyamat Kulon Village Analysis Area.

\begin{tabular}{|c|c|c|c|c|c|}
\hline \multirow[b]{2}{*}{ Channel } & \multirow{2}{*}{$\begin{array}{l}\text { Normalization } \\
(\mathrm{m})\end{array}$} & \multirow{2}{*}{$\begin{array}{l}\text { Rehabilitation } \\
\text { (m) }\end{array}$} & \multirow{2}{*}{$\begin{array}{c}\text { New } \\
\text { Development } \\
(\mathrm{m}) \\
\end{array}$} & \multicolumn{2}{|c|}{ Drainage Average Condition } \\
\hline & & & & $\begin{array}{l}\text { Without Maintenance } \\
(\mathrm{m})\end{array}$ & $\begin{array}{l}\text { With Maintenance } \\
(\mathrm{m})\end{array}$ \\
\hline Irrigation & 100 & 555 & 0 & - & 76.48 \\
\hline Primary & 2050 & 0 & 0 & - & 63.97 \\
\hline Secondary & 577 & 70 & 0 & 66.68 & 85.56 \\
\hline Tertiary & 0 & 0 & 345 & 67.99 & 71.77 \\
\hline
\end{tabular}


As illustrated in Table 10, normalization activities are focused on the primary channel and have been applied to $2050 \mathrm{~m}$ of the primary channels, which means that they were applied to all primary channels in this analysis area. Around $577 \mathrm{~m}$ of secondary channel was cleaned as well as $100 \mathrm{~m}$ of irrigation channel. Channel repairs are concentrated on the irrigation channels and new developments are dedicated to the tertiary channel.

Because the drainage system in this area is insufficient to accommodate rainwater, drainage capacity received the same score in all catchment areas. This condition raises the chance of inundation across the study area. However, because of the high elevation and slope conditions, some areas have low inundation risk scores. The high-risk inundation area is in the northern part of the analysis area that has a lower elevation. Inundations occur annually in locations with a high inundation risk score. Inundations do not occur in the southern part of the analysis area with higher elevation, confirming the significantly high contribution of elevation and slope to inundation propensity.

\section{d. Tunon, Keturen, Bandung, Debong Kidul and Debong Tengah Village Analysis Area (Analysis Area 4)}

The water runoff and drainage capacity comparison in Table 11 shows that the inundation problem is not caused by drainage capacity, because the total secondary channel capacity is higher than the required capacity for a 10 -year return period analysis. The risk only occurs in subsystem 5 , where the current capacity is not sufficient for 5 and 10 -years of rainfall intensities. However, without sedimentation build up, the drainage maximum capacity is higher than the runoff.

Table 11. Tunon, Keturen, Bandung, Debong Kidul and Debong Tengah village Drainage Capacity Calculation Result.

\begin{tabular}{|c|c|c|c|c|c|c|}
\hline \multirow[b]{2}{*}{$\begin{array}{c}\text { Catchment } \\
\text { Area }\end{array}$} & \multicolumn{3}{|c|}{ Capacity Requirement } & \multicolumn{3}{|c|}{ Drainage Capacity } \\
\hline & $\begin{array}{c}\text { 2-years } \\
\text { Return } \\
\text { Period (L/s) } \\
\end{array}$ & $\begin{array}{c}\text { 5-years } \\
\text { Return } \\
\text { Period (L/s) }\end{array}$ & $\begin{array}{c}\text { 10-years } \\
\text { Return } \\
\text { Period (L/s) }\end{array}$ & $\begin{array}{c}\text { Maximum } \\
\text { Drainage } \\
\text { Capacity (L/s) }\end{array}$ & $\begin{array}{c}\text { Drainage Capacity } \\
\text { Without Sediment } \\
(\mathrm{L} / \mathrm{s})\end{array}$ & $\begin{array}{c}\text { Planned } \\
\text { Drainage } \\
\text { Capacity (L/s) }\end{array}$ \\
\hline Subsystem 1 & 3.126 & 4.275 & 5.264 & 18.738 & 12.963 & 0.510 \\
\hline Subsystem 2 & 2.551 & 3.488 & 4.295 & 10.665 & 13.563 & 5.440 \\
\hline Subsystem 3 & 1.045 & 1.429 & 1.760 & 2.531 & 4.145 & 5.046 \\
\hline Subsystem 4 & 2.763 & 3.778 & 4.652 & 5.131 & 10.098 & 27.956 \\
\hline Subsystem 5 & 2.280 & 3.118 & 3.839 & 2.531 & 4.145 & 5.046 \\
\hline Subsystem 6 & 0.934 & 1.276 & 1.572 & 7.069 & 12.372 & 12.371 \\
\hline
\end{tabular}

Numerous urban drainage maintenance treatments have been carried out in this inundation area, resulting in distinct effects on each channel. A sporadic tertiary drainage cleaning and a low level of community participation in the five villages lead to the degradation of tertiary drainage channel conditions over time. Secondary drainage also indicates a deficiency in performance, although massive cleaning has been done on this channel. Improvement on drainage channel only appears in the primary channel, in which the stream is collected from a secondary channel with a $10 \%$ increase. However, the network of drainage channel in this area is categorized as good compared to other areas. More massive drainage cleanup is required to overcome the accelerated rate of sediment accumulation.

Table 1. Summary of Maintenance Activities in of Tunon, Keturen, Bandung, Kalinyamat Wetan and Kalinyamat Kulon Village Analysis Area.

\begin{tabular}{|l|r|r|r|r|r|}
\hline \multicolumn{1}{|c|}{ Channel } & \multirow{2}{*}{$\begin{array}{c}\text { Normalization } \\
(\mathbf{m})\end{array}$} & \multirow{2}{*}{$\begin{array}{c}\text { Rehabilitation } \\
(\mathbf{m})\end{array}$} & \multicolumn{2}{c|}{$\begin{array}{c}\text { New } \\
\text { Development } \\
(\mathbf{m})\end{array}$} & \multicolumn{2}{|c|}{$\begin{array}{c}\text { Drainage Average Condition } \\
\text { Without }\end{array}$} & $\begin{array}{c}\text { With } \\
\text { Maintenance (\%) }\end{array}$ & Maintenance (\%) \\
\hline Irrigation & 0 & 0 & 0 & 49.81 & no activity \\
\hline Primary & 2072 & 0 & 0 & 57.27 & 67.72 \\
\hline Secondary & 6450 & 129 & 0 & 78.13 & 73.48 \\
\hline Tertiary & 185 & 0 & 388 & 61.00 & 48.21 \\
\hline
\end{tabular}

The Tunon, Keturen, Bandung, Debong Kidul, and Debong Tengah villages, inundation analysis areas are located at a relatively high elevation with good drainage capacity. However, the land and drainage slope in many parts of the area are relatively mild. Regular road infrastructure construction and repair that place material without dredging increase the road elevation over time, and in some old houses, 
the floor elevation is now lower than the road. To reduce inundation, the drainage water level needs to be maintained so that water flowing in the drainage channel continues to flow without obstacles.

\section{e. Tegalsari, Keraton, Pekauman and Pesurungan Kidul Village Analysis Area (Analysis Area 5)}

Table 2. Tegalsari, Keraton, Pekauman, and Pesurungan Kidul Village Drainage Capacity Calculation Result.

\begin{tabular}{|c|c|c|c|c|c|c|}
\hline \multirow[b]{2}{*}{$\begin{array}{c}\text { Catchment } \\
\text { Area }\end{array}$} & \multicolumn{3}{|c|}{ Capacity Requirement } & \multicolumn{3}{|c|}{ Drainage Capacity } \\
\hline & $\begin{array}{c}2 \text { Years } \\
\text { Return } \\
\text { Period (L/s) }\end{array}$ & $\begin{array}{c}5 \text { Years } \\
\text { Return } \\
\text { Period (L/s) }\end{array}$ & $\begin{array}{c}10 \text { Years } \\
\text { Return } \\
\text { Period (L/s) }\end{array}$ & $\begin{array}{c}\text { Maximum } \\
\text { Drainage Capacity } \\
\text { (L/s) }\end{array}$ & $\begin{array}{c}\text { Drainage Capacity } \\
\text { Without Sediment } \\
\text { (L/s) }\end{array}$ & $\begin{array}{c}\text { Planned } \\
\text { Drainage } \\
\text { Capacity (L/s) }\end{array}$ \\
\hline Subsystem 1 & 3.083 & 4.215 & 5.190 & 1.220 & 1.714 & 1.457 \\
\hline Subsystem 3 & 3.521 & 4.815 & 5.929 & 1.724 & 3.016 & 3.049 \\
\hline Subsystem 2 & 4.768 & 4.107 & 5.057 & 0.244 & 0.320 & 0.320 \\
\hline Subsystem 5 & 2.763 & 3.778 & 4.652 & 3.107 & 6.523 & 0.324 \\
\hline \multirow[t]{2}{*}{ Subsystem 4} & 0.596 & 0.815 & 1.004 & 7.578 & 15.755 & 74.218 \\
\hline & 14.731 & 17.730 & 21.832 & 11.823 & 25.419 & 72.774 \\
\hline Subsystem 6 & 0.616 & 0.842 & 1.037 & 1.019 & 1.019 & 1.681 \\
\hline \multirow[t]{3}{*}{ Subsystem 7} & 2.865 & 3.918 & 4.824 & 0.089 & 0.089 & 0.350 \\
\hline & 3.481 & 4.760 & 5.861 & 1.540 & 1.540 & 33.894 \\
\hline & 18.212 & 22.490 & 27.693 & 20.693 & 61.671 & 88.945 \\
\hline
\end{tabular}

Bordered by a secondary channel in the north, a main road in the east and south, and a river in the west, the analysis area measures approximately 65.2 ha-twice as large as the inundation area. The analysis location is divided into seven subsystems, each of which has a different area determined by a watershed and secondary channel. Water runoff capacity is calculated using a 6-hour rainfall intensity for 2,5 , and 10 -years return periods. The calculation results are compared with the maximum capacity of the secondary drainage function as the collector channel in each subsystem.

The results of the secondary ditch capacity calculation and analysis show that most of the secondary channel capacity is lower than the volume of water runoff, even in the 2-years return period of rainfall. The current condition of the secondary channel can only accommodate rainfall in the catchment area in the subsystems 4,5 , and 6 . Without sedimentation build up, all the primary channels are in optimum condition to accommodate rainwater; however, in the current high-sediment condition, they simply do not have the capacity.

Table 3. Summary of Maintenance Activities in of Tegalsari, Keraton, Pekauman and Pesurungan Kidul Village Analysis Area.

\begin{tabular}{|c|c|c|c|c|c|}
\hline \multirow[b]{2}{*}{ Channel } & \multirow{2}{*}{$\begin{array}{l}\text { Normalization } \\
\text { (m) }\end{array}$} & \multirow{2}{*}{$\begin{array}{l}\text { Rehabilitation } \\
\qquad(\mathrm{m})\end{array}$} & \multirow{2}{*}{$\begin{array}{c}\text { New } \\
\text { Development } \\
(\mathrm{m}) \\
\end{array}$} & \multicolumn{2}{|c|}{ Drainage Average Condition } \\
\hline & & & & $\begin{array}{l}\text { Without Maintenance } \\
\text { (\%) }\end{array}$ & $\begin{array}{l}\text { With Maintenance } \\
\text { (\%) }\end{array}$ \\
\hline Primary & 2728 & 0 & 0 & 50.00 & 63.31 \\
\hline Secondary & 990 & 361.15 & 0 & 51.24 & 62.53 \\
\hline Tertiary & 500 & 1630.85 & 815.6 & 67.59 & 74.14 \\
\hline
\end{tabular}

\subsubsection{Inundation Risk Map}

The inundation risk map was created by overlaying the elevation, slope, and drainage sufficiency maps based on previous calculations. Because drainage sufficiency was only available in the chosen inundation area, inundation map analysis will be focused on those inundation sites. 

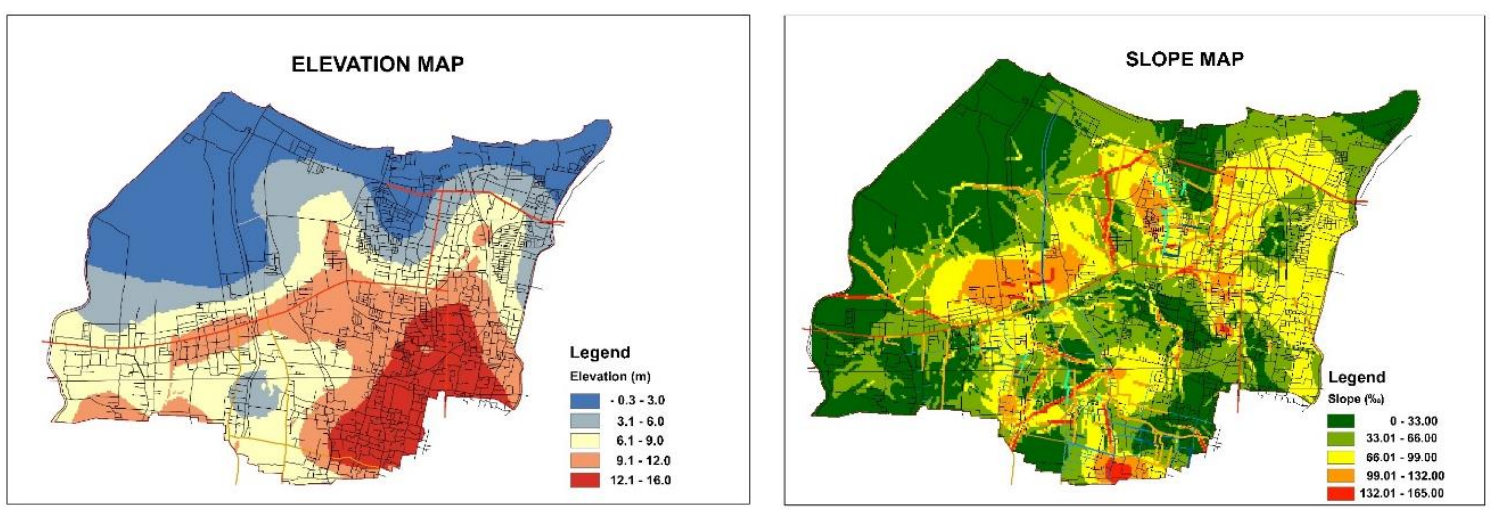

Figure 1. Tegal Elevation Map (left) and Slope Map (right).

Based on the drainage overlay map, we can see that most of the chosen inundation analysis areas have various levels of inundation risk from moderate (6) to high (10). Each maintenance activity in a specific area has a different impact on drainage conditions and inundation reduction. The details of inundation location and reduction in each of the analysis areas are illustrated in Table 15.

The implementation of drainage maintenance provides a major contribution in reducing the level of inundation in four locations. However, the proportion is different for each area, which is in line with the unique location characteristics, because the inundation in each area is caused by various factors, including performance of the drainage system and its lengths. Secondary drainage cleaning and repair significantly improve its effectiveness in reducing stormwater. Secondary drainage cleaning also contributes more significantly in maintaining the efficiency of secondary channels than secondary drainage repair. More actions need to be regularly implemented to eliminate the inundation area.

The implementation of urban drainage maintenance reduces the inundation risk by 1-3 levels, depending on location's characteristics. In the analysis areas 1 and 4, which are located at higher elevations, the inundation risk level decreased to levels 5 and 6; although inundation did not occur in 2020, the risk and the possibility of inundation are still high. Compared to the analysis areas 1 and 4 , the inundation risk at sites 2,3 , and 5 (at a lower elevation) is relatively higher because drainage maintenance activity only affects drainage condition and does not affect the elevation and drainage slope.

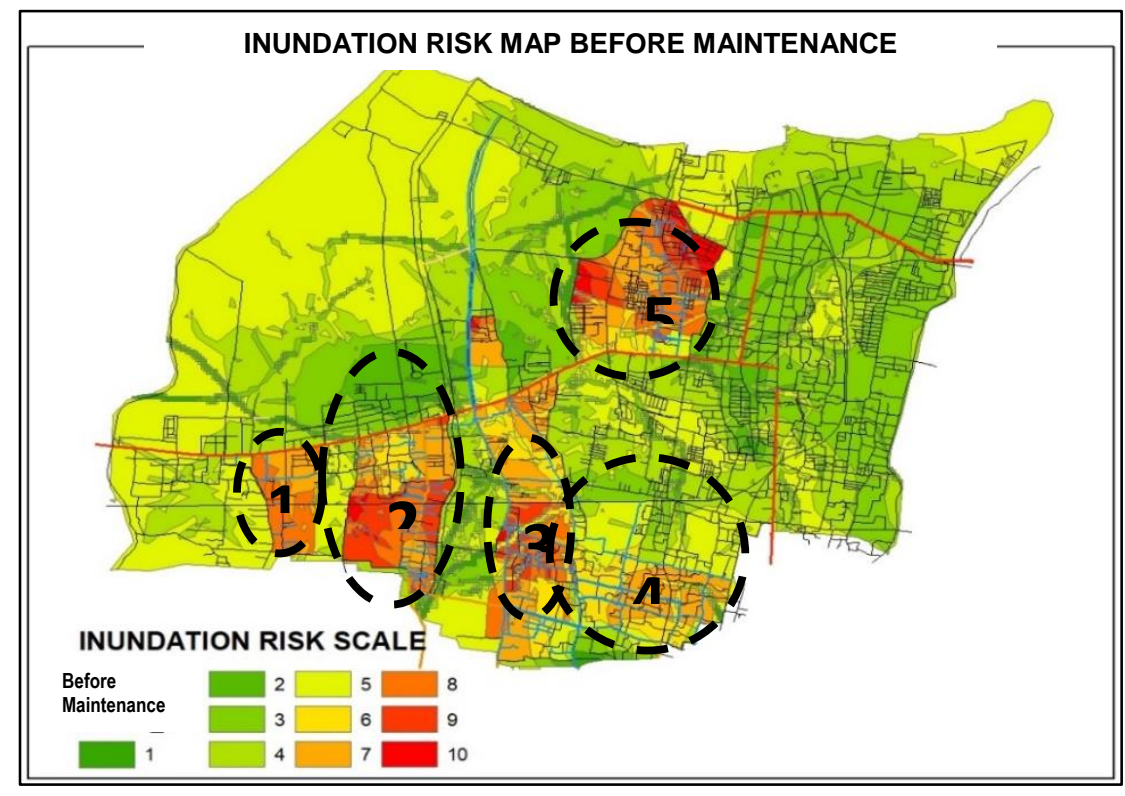

Figure 2. Inundation Risk Map Before Drainage Maintenance. 


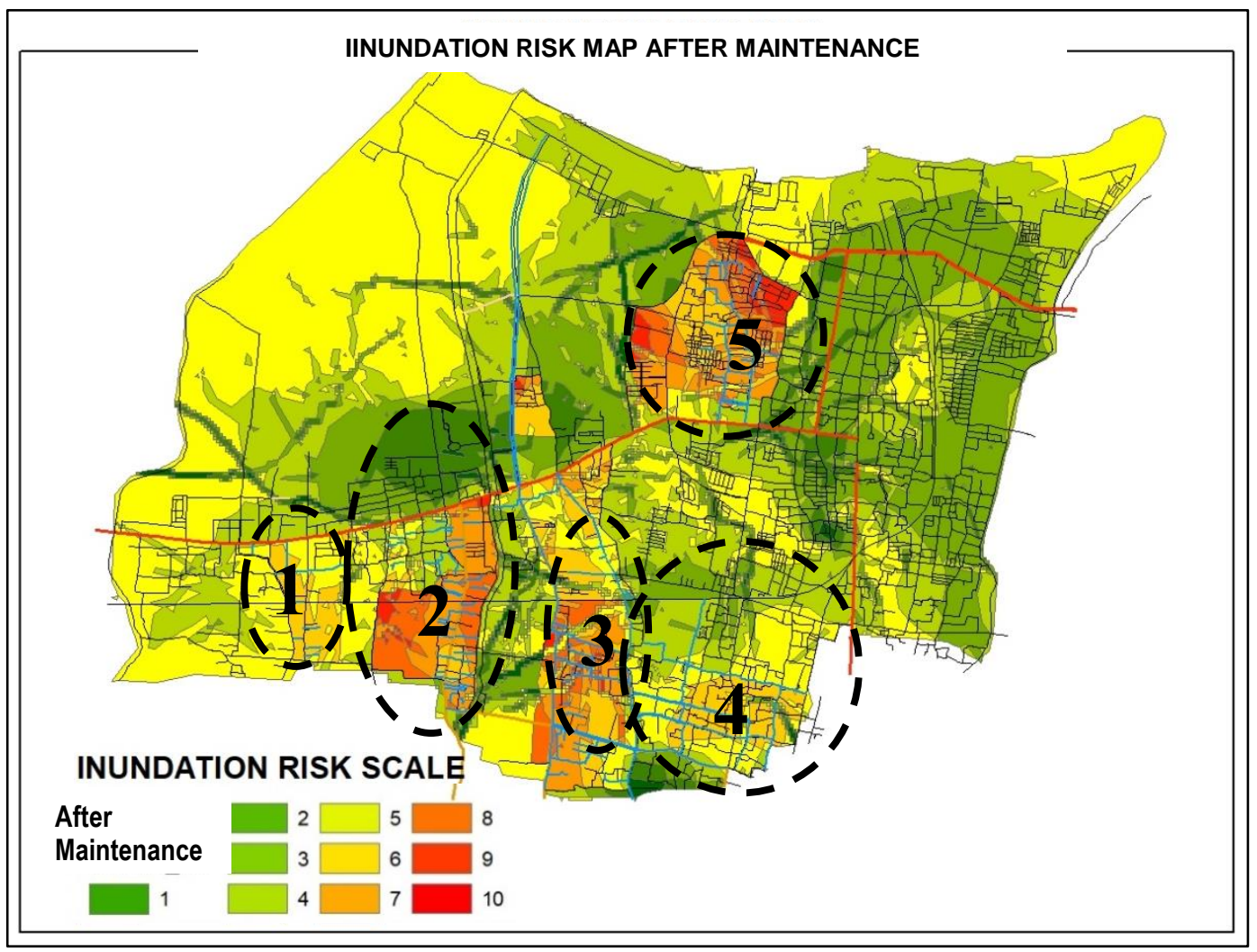

Figure 3. Inundation Risk Map After Drainage Maintenance.

Table 4. Inundation Area, Maintenance Activity and Current Average Drainage Condition in Each Inundation Area.

\begin{tabular}{|c|c|c|c|c|c|c|c|c|c|}
\hline \multirow[b]{2}{*}{ Inundation Area } & \multicolumn{3}{|c|}{ Inundation Area (ha) } & \multicolumn{2}{|c|}{ Secondary Channel } & \multicolumn{3}{|c|}{ Tertiary Channel } & \multirow[b]{2}{*}{$\begin{array}{l}\text { Average } \\
\text { Drainage } \\
\text { Condition }\end{array}$} \\
\hline & $\begin{array}{c}2011 \\
\text { (Hazard } \\
\text { Map) }\end{array}$ & $\begin{array}{c}2020 \\
\text { (February } \\
\text { Survey) }\end{array}$ & $\begin{array}{c}\text { Reduct } \\
\text { ion }\end{array}$ & $\begin{array}{l}\text { Norma } \\
\text { lization } \\
\text { (m) }\end{array}$ & $\begin{array}{l}\text { Rehabilit } \\
\text { ation }(\mathrm{m})\end{array}$ & $\begin{array}{l}\text { Norma } \\
\text { lization } \\
\text { (m) }\end{array}$ & $\begin{array}{l}\text { Rehabilit } \\
\text { ation }(\mathrm{m})\end{array}$ & $\begin{array}{c}\text { New } \\
\text { Channel } \\
\text { (m) }\end{array}$ & \\
\hline Cabawan & 13.95 & 0 & 13.95 & 1189.0 & 0.0 & 0.0 & 0.0 & 0.0 & 56.89 \\
\hline $\begin{array}{l}\text { Kalinyamat Kulon, } \\
\text { Margadana, and } \\
\text { Sumurpanggang }\end{array}$ & 75.40 & 17.57 & 57.83 & 2625.0 & 726.0 & 1880.0 & 139.0 & 644.0 & 67.00 \\
\hline $\begin{array}{l}\text { Tunon, Bandung, } \\
\text { Kalinyamat Kulon, } \\
\text { and Keturen }\end{array}$ & 56.80 & 65.70 & -8.90 & 2727.0 & 625.0 & 0.0 & 0.0 & 345.0 & 67.24 \\
\hline $\begin{array}{l}\text { Bandung, Tunon, } \\
\text { Keturen, and } \\
\text { Debong Tengah }\end{array}$ & 63.17 & 0 & 63.17 & 7100.0 & 129.0 & 0.0 & 0.0 & 787.0 & 69.93 \\
\hline $\begin{array}{l}\text { Tegalsari and } \\
\text { Keraton }\end{array}$ & 52.61 & 20.06 & 32.55 & 3718.0 & 361.2 & 500.0 & 1269.7 & 815.6 & 70.72 \\
\hline
\end{tabular}

\subsection{Social Analysis}

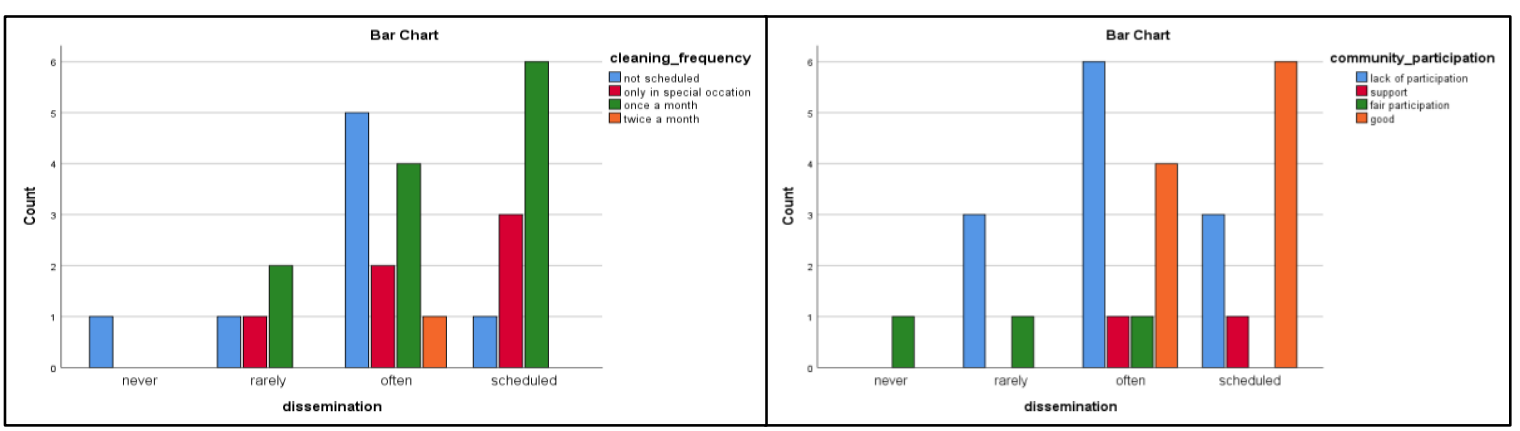

Figure 4. Dissemination of Drainage Maintenance Influence in Drainage Cleaning Frequency (left) and Community Participation in Drainage Maintenance (right). 
Crosstab analysis was conducted to determine the effect of information dissemination frequency on urban drainage cleaning by the community and community participation. According to the crosstabulation results, activities related to dissemination of public information in the 12 villages are carried out 3 or 4 times a year and have been scheduled for more than 5 times in the other 10 villages. The cleaning frequency in villages that never or rarely received the relevant information from the local government is relatively low and no urban drainage cleaning is scheduled and community participation simply does not exist. Villages that receive information regularly are more likely to carry out drainage channel sediment cleanup once a month and in most cases show active community participation. However, villages that engage in frequent socialization show a relatively less community participation with no scheduled drainage maintenance activity. This result indicates that to increase the frequency and community participation in urban drainage cleaning, the dissemination activity should be scheduled periodically at least 5 times per year. In addition to the city government, the village chief and government should also assume the responsibilities and participate in this activity to increase the social effect of urban drainage maintenance.

\section{Conclusions}

Below are the multi-layered processes associated with the implementation of urban drainage maintenance to reduce the risk of inundation in the city of Tegal:

- The implementation of combined drainage networks quickly creates ditch sediment; thus, countless maintenance activities have been performed but they are insufficient in some places and even lead to poor drainage conditions.

- Two types of problems generally exist in the activities associated with urban drainage maintenance: i.e., social problems, which are caused by human behaviors and technical problems, which are caused by water stream process. Social problems include community behavior, law enforcement, institutional coordination, and data sufficiency. Technical problems include insufficient channel dimension, low elevation, the implementation of combined drainage networks, vegetation, and poorly placed drainage locations under buildings.

- The impacts of urban drainage maintenance differ by area because different locations have their own unique characteristics and problems and must be individually treated.

- Ditch sediment cleaning has a larger impact on urban drainage improvement than other maintenance activities in almost all analysis areas. However, the sedimentation level at some sites remains high due to rapid sediment accumulation. In lower elevation areas, sediment cleaning must be followed by further water runoff controls, such as sluice gates operations, and water pumps installation. Drainage treatment must be adjusted to site characteristics and cannot be generalized.

- Local government, as the principal driver in drainage maintenance activity, plays a fundamental role in increasing the frequency of drainage maintenance, because all drainage maintenance activates are closely associated and organized by the local governments. Furthermore, the regional government has the obligation to increase community involvement in drainage maintenance activities.

\section{Acknowledgments}

I would like to express my deep appreciation to the National Development Planning Agency (Bappenas) of the Republic of Indonesia for offering a scholarship for a Master's degree linkage program at Universitas Gadjah Mada and Ritsumeikan University. I would also like to thank Professors Ichiki Atsushi, Shimizu Toshiyuki Sensei, and Ibu Dewanti for their patience in guiding me during the research process.

\section{Reference}

Authority, N. D. (2015). Risiko Bencana Indonesia. Jakarta: BNPB.

Davies, D. B. (2000). Urban Drainage. New York: E \& FN Spon.

Esri Press Team. (2018). How to Perform Spatial Analysis.

Faiz Isma, I. Y. (2018). Sistem Informasi Geografis (Sig) Sebagai Evaluasi Jaringan Drainase di Gampong Sungai Pauh Kota Langsa. Jurutera, 12.

Government, T. L. (2019). Rancangan Peraturan Daerah (RAPERDA) RPJMD Kota Tegal 2019-2024. Tegal: 
Bappeda Kota Tegal.

Jonatan Zischg, B. R. (2018). Future trajectories of urban drainage systems: A simple exploratory modeling approach for assessing socio-technical transitions. Elsevier B.V, 11.

Kementerian Kelautan dan Perikanan. (2019). Laut Masa Depan Bangsa, Mari Jaga Bersama.

Ngamalieu-Nengoue, U. A., Iglesias-Rey, P. L., Martínez-Solano, F. J., Mora-Meliá, D., \& Valderrama, J. G. S. (2019). Urban Drainage Network Rehabilitation Considering Storm Tank Installation and Pipe Substitution. Multidisciplinary Digital Publishing Institute Journal, 11(3).

Suripin. (2004). Sistem Drainase Perkotaan yang Berkelanjutan. Yogyakarta: ANDI OFFSET.

Suryadiputra, N. (2012). Mangrove Mengamankan Pesisir yang Rentan Bencana.

Tiede, D. (2014). A new geospatial overlay method for the analysis and visualization of spatial change patterns using object-oriented data modeling concepts. Cartography and Geographic Information Science, 41.

Yazdi, J. (2017). Rehabilitation of Urban Drainage Systems Using a resilience-based Approach. Water Resources Management, 32.

Yongchao Zhou, D. S. (2019). Urban Flood Risk Assessment Using Storm Characteristic Parameters Sensitive to Catchment-specific Drainage System. Science of The Total Environment, 659. 